\title{
Thymoma complicated by deep vein thrombosis of the arm
}

\author{
Stephen L Ball, ${ }^{1,2}$ Helen C Cocks ${ }^{1}$
}

${ }^{1}$ Department of ENT Surgery, City Hospitals Sunderland, Sunderland, UK

${ }^{2}$ Institute of Cellular Medicine, Newcastle University, Newcastle upon Tyne, Tyne \& Wear, UK

\section{Correspondence to}

Stephen L Ball,

s.l.ball@ncl.ac.uk

Accepted 4 December 2015

\section{DESCRIPTION}

Our patient was referred urgently with an anterior neck lump. The patient was otherwise well with no history of smoking or radiation exposure. Initial investigation with ultrasound-guided aspiration cytology was suspicious and atypical for thyroid carcinoma. A CT scan demonstrated the neck lump was part of a $64 \times 56 \times 54 \mathrm{~mm}$ retrosternal mass infiltrating the superior vena cava and atrium (figure 1).

Surgical biopsy and histological analysis demonstrated a mixed widely invasive thymoma P1 prominent with some P2 elements, Masaoka stage 3. A positron emission tomography-CT scan was arranged to identify any signs of metastasis (figure 2). Following extensive discussion between different specialities and centres, a surgical debulking thymectomy was performed, followed by adjuvant chemoradiotherapy. Following surgical resection, the tumour was staged as pT3N0M0. The tumour showed a good response to an ABVD regime (doxorubicin, bleomycin, vinblastine, dacarbazine) of chemotherapy and 54 Grey of radiotherapy split into 30 fractions over 42 days with a multiple conformal field technique.

After a good response to treatment, our patient had 18 months of disease remission, though,

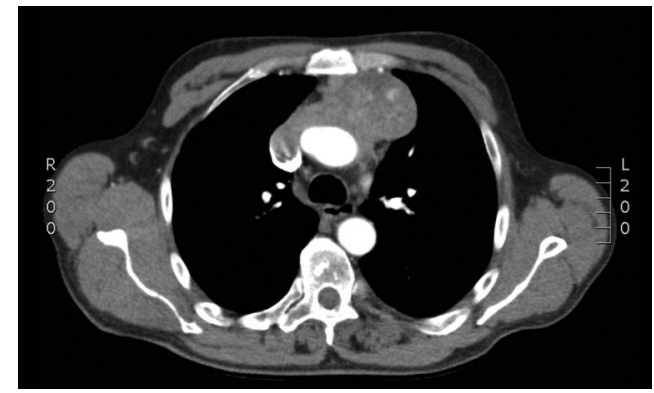

Figure 1 CT scan demonstrating deep extension of retrosternal lesion into the anterior mediastinum, where a more focal $64 \times 56 \times 54 \mathrm{~mm}$ mass is seen. The mass is partly cystic, centred towards the left of the anterior mediastinum, and directly infiltrates the superior vena cava and atrium.

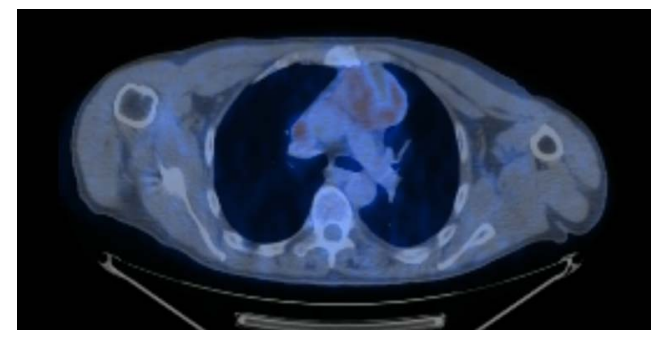

Figure 2 Fluorodeoxyglucose (FDG) labelled positron emission tomography-CT scan following injection of $352 \mathrm{Mbq}$ of FDG. The $6 \mathrm{~cm}$ anterior mediastinal mass (as shown in figure 1) demonstrating irregularly increased FDG uptake. No local or distant metastasis was seen.

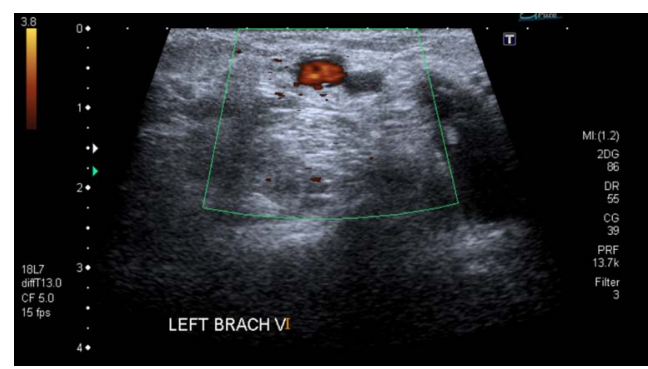

Figure 3 Doppler ultrasound of left upper limb veins. Ultrasound showing thrombus formation in the brachial vein. Doppler showing normal flow in the adjacent brachial artery (orange/yellow), while there is no demonstrable flow in the vein, consistent with the clinical picture of upper limb deep vein thrombosis.

unfortunately, during his surveillance, a CT scan identified disease recurrence. He also developed an acute swelling of the left arm shown by ultrasound to be a thrombus of the brachial, axillary and subclavian veins extending to the internal jugular vein (figure 3 ). This was successfully treated with anticoagulation consisting of low molecular weight heparin and direct factor $\mathrm{Xa}$ inhibitor (rivaroxaban). Following further multidisciplinary discussion, a regime of palliative chemotherapy has been started, though due to the rare nature of post-treatment recurrence it is difficult to offer accurate survival estimates. ${ }^{1}$

\section{Learning points}

- Rare malignancies such as this require expertise of multiple specialties and, often, collaboration with specialist centres.

- Deep vein thromboses of the upper extremities can result from or be an indication of significant underlying disease.

- Anterior neck lumps do not always arise from the thyroid.

Acknowledgements We would like to acknowledge the help and participation of our patient in preparation of this case report.

Competing interests None declared.

Patient consent Obtained.

Provenance and peer review Not commissioned; externally pee reviewed.

\section{REFERENCE}

1 Lombe DC, Jeremic B. Review of the Place and Role of Radiotherapy in Thymoma. Clin Lung Cancer 2015;16:406-12. 
Copyright 2015 BMJ Publishing Group. All rights reserved. For permission to reuse any of this content visit http://group.bmj.com/group/rights-licensing/permissions.

BMJ Case Report Fellows may re-use this article for personal use and teaching without any further permission.

Become a Fellow of BMJ Case Reports today and you can:

- Submit as many cases as you like

- Enjoy fast sympathetic peer review and rapid publication of accepted articles

- Access all the published articles

- Re-use any of the published material for personal use and teaching without further permission

For information on Institutional Fellowships contact consortiasales@bmjgroup.com

Visit casereports.bmj.com for more articles like this and to become a Fellow 